\title{
SPERM COLLECTION FROM SHOT RED DEER STAGS (CERVUS ELAPHUS) AND THE UTILISATION OF SPERM FROZEN AND SUBSEQUENTLY THAWED
}

\author{
Z. ZOMBORSZKY ${ }^{1 *}$, T. ZUBOR ${ }^{2}$, J. TÓTH ${ }^{3}$ and P. HORN ${ }^{1}$ \\ ${ }^{1}$ Faculty of Animal Science, Pannon University of Agriculture, H-7401 Kaposvár, \\ P.O. Box 16, Hungary, ${ }^{2}$ Embryo Ltd., Pécs, Hungary, ${ }^{3}$ Pannon Equestrian Academy \\ and Specialist Secondary School for Agriculture, Kaposvár, Hungary
}

(Received October 26, 1998; accepted December 21, 1998)

\begin{abstract}
Sperm samples were collected from the epididymides of 11 hunter-killed stags (Cervus elaphus hippelaphus) within 2 to $17 \mathrm{~h}$ post mortem in September 1991. Progressively motile spermatozoa were diluted and deep-frozen in tris-yolk extender by a procedure routinely used for bovine semen. The pre-freezing motility of spermatozoa from 6 stags was higher than $80 \%$, while the sperm of 5 animals was found to be unsuitable for dilution. In the post-thawed sperm of six stags $40-50 \%$ of the spermatozoa showed progressive motility and the number of viable spermatozoa ranged from 8.6 to $26.7 \times 10^{6}$ per $0.25 \mathrm{ml}$ straw. Two years later, three hinds were superovulated by the use of a progesterone-releasing intravaginal device (CIDR type G, Carter, Holt Harvey Plastic Products Group Ltd., Hamilton, New Zealand) for a period of 14 days and with follicle stimulating hormone (Folicotropin inj., Spofa, Prague). Each hind was inseminated artificially $60 \mathrm{~h}$ after the withdrawal of CIDR with thawed sperm injected into the uterus via the vagina. Seven days later the uteri were flushed out, as a result of which 3 early blastocysts +1 ovum, 3 morulae +4 ova, and 1 morula +7 ova, respectively, were recovered from the three hinds. Deer embryos were frozen according to a glycerolbased freezing protocol. A further two years later two hinds were oestrussynchronised with CIDR type G and 300 IU PMSG (Folligon inj., Intervet, NL), and two of the thawed embryos were transplanted into two recipient hinds 7 days after heat. One of these gave birth to a normal stag fawn in June 1996. This was the first deer born in Hungary from embryo transfer. The results obtained indicate that sperm from top stags shot in the course of hunting can prove useful for the preservation of genetic material or in the development of the farmed deer system.
\end{abstract}

Key words: Artificial insemination, embryo transfer, red deer, sperm preservation

The value traits, trophy and body mass of red deer (Cervus elaphus hippelaphus) native to Hungary are recognised throughout the world. The mainte-

*E-mail: ZZomborszky@atk.kaposvar.pate.hu; Fax: 3682320175 
nance and improvement of genetic potential can be facilitated by means of captive animal breeding programmes. Farming of red deer offers the facilitation of genetic progress via biotechnological reproduction programmes, this not only being indispensable with respect to animal breeding but also being of significant national interest in the preservation of one of the valuable assets of Hungary. The objective of these investigations was to create the potential for the establishment of a national red deer sperm bank.

The collection of semen from red deer stags and the quantitative parameters characteristic of semen were first reported by Krzywinski (1976), while the use of frozen-thawed semen for the artificial insemination of hinds was reported by Krzywinski and Jaczewski (1978). Electroejaculation as a method for semen collection from red deer and wapiti (Cervus elaphus canadiensis) and the correlation between seasonal changes and semen volume and quality have been outlined by Jaczewski et al. (1976) and Haigh et al. (1985). Previous studies have evaluated the viability of semen obtained by electroejaculation in Père David's deer, Elaphurus davidianus (Asher et al., 1988a), fallow deer, Dama dama (Asher et al., 1988b; Mulley et al., 1988), and white-tailed deer, Odocoileus virginianus (Haigh, 1984; Jacobson et al., 1989). Experimental results obtained from intrauterine artificial insemination carried out via the vagina or by a laparoscopic technique in farmed red deer hinds were reported in a comprehensive paper by Fennessy et al. (1990). Haigh and Bowen (1991) used frozen-thawed semen taken from wapiti stags for laparoscopic insemination of oestrus-synchronised red deer hinds. Jacobson et al. (1989) reported the collection and subsequent deep-freezing of sperm from the epididymides of two dead white-tailed deer, and the successful use of such sperm for insemination. Hunter-killed male cervids may represent a readily available source of sperm for captive breeding programmes for many cervid species, but the viability of such sperm has not yet been subjected to extensive testing. In this study the objective was to evaluate the viability and effectiveness of deepfrozen sperm collected from the epididymides of red deer stags shot in the wild. This would facilitate the establishment of a gene bank consisting of material originating from shot wild animals, the insemination of oestrus-synchronised hinds by the use of deep-frozen sperm, and the production of embryos from superovulated individuals.

\section{Materials and methods}

Of the red deer stags hunter-killed in south-western Hungary during the roaring season including the period 5 through 17 September 1991, only those with high trophy value and body mass were included in this study. After shooting, the stags were eviscerated and their testicles removed. If a stag was shot in the morning, its sperm was collected the same morning, while sperm was col- 
lected the following morning from those killed in the evening. Thus, the collection and dilution of sperm began between 2 and $17 \mathrm{~h}$ post mortem.

The stock solution for extending spermatozoa was prepared as follows. First, $30.28 \mathrm{~g} 0.2 \mathrm{M}$ tris-(hydroxymethyl)-aminomethane, $12.5 \mathrm{~g}$ fructose and $17.0 \mathrm{~g}$ citric acid were added to $850 \mathrm{ml} \mathrm{H}_{2} \mathrm{O}$ in a sterilised glass bottle. The $\mathrm{pH}$ was adjusted to 6.8 , subsequent to which the solution was sterilised for $5 \mathrm{~min}$, then supplemented with antibiotic (1.26 g Sigmamycin), and divided into two equal volumes. Eighty $\mathrm{ml}$ bi-distilled water was added to one of these volumes, which became diluent A; $125 \mathrm{ml}$ fresh egg yolk was then added to both parts, and $80 \mathrm{ml}$ glycerol was added to the second volume, to form diluent B. The diluents were stored frozen until used. The solutions were drawn into disposable $10 \mathrm{~cm}^{3}$ plastic syringes for dilution.

Sperm collection involved the aseptic exposure of the epididymides and the extraction of the sperm mass from the caudal end of the epididymis through the vas deferens by means of massage into a sterile disposable plastic Petri dish. Subsequently, the epididymal ducts (ductus epididymides and vas deferens) were exposed and rinsed with $1.0 \mathrm{ml}$ glycerol-free tris-yolk diluent $\mathrm{A}$ at room temperature $\left(20^{\circ} \mathrm{C}\right)$. This method provided approximately $0.3-0.6 \mathrm{ml}$ sperm mass from each epididymis; thus, the total volume of sperm collected was approximately $1.0 \mathrm{ml}$. Final dilutions were prepared only from sperm samples containing more than $80 \%$ viable sperm showing progressive motility. In such cases a final dilution was prepared with the remaining $8.0 \mathrm{ml}$ glycerol-free tris-yolk diluent $\mathrm{A}$ and $10.0 \mathrm{ml}$ glycerol-containing tris-yolk diluent $\mathrm{B}$ at $4{ }^{\circ} \mathrm{C}$. Fractionated dilutions were prepared, in a sterile glass vessel, within $8 \mathrm{~min}$ (A) and $10 \mathrm{~min}$ (B). During dilution the Petri dish and the glass vessel were rotated to facilitate homogenisation. Diluted sperm was transported and stored at $4{ }^{\circ} \mathrm{C}$ in a thermos flask containing ice cubes. After equilibration the diluted sperm was distributed into serially marked, $0.25 \mathrm{ml}$ straws and deep-frozen in a programmable freezer, then transferred into liquid nitrogen for storage. Sperm samples suitable for deep-freezing were frozen between 9 and $40 \mathrm{~h}$ after the stag's death. The quantitative and qualitative evaluation of frozen and subsequently thawed sperm samples was performed at the National Institute for Agricultural Quality Control, in accordance with Hungarian Standard MSz 7061 (1987).

For in vivo experiments with deep-frozen sperm obtained from the epididymis, in 1993 superovulation was induced in three multiparous hinds (age: 46 years; body mass: $120-140 \mathrm{~kg}$ ). Long-term progesterone treatment (CIDR type $\mathrm{G}$ intravaginal device) was provided for 14 days. The hinds were restrained in a crush while the vaginal implant was inserted. Superovulation was induced by the administration of FSH injection (Folicotropin inj.) at 12-h intervals for 4 days, beginning on the $12^{\text {th }}$ day after insertion of the implant. 
Single intrauterine insemination of the hinds was performed $60 \mathrm{~h}$ after CIDR withdrawal, through the cervix. In this experiment the sperm was thawed at $37^{\circ} \mathrm{C}$ for $1 \mathrm{~min}$, marked 2a (containing $23.5 \times 10^{6}$ spermatozoa showing progressive motility per $0.25 \mathrm{ml}$ ) and used for insemination. The collection of embryos, on day 7 after insemination, involved laparotomy followed by the flushing of each uterine horn with $100 \mathrm{ml} 37^{\circ} \mathrm{C}$ Dulbecco's phosphate buffer solution containing $20 \%$ fetal calf serum, using a Foley catheter. The filtrate from the flushing fluid was examined under a stereomicroscope at $50 \times$ magnification to identify embryo characteristics. After a one-stage water extraction with $10 \%$ glycerol, early blastocysts and morulae with an intact zona pellucida were drawn into a $0.25 \mathrm{ml}$ plastic straw. They were then frozen according to a protocol developed for cattle embryos (Curtis, 1991).

After two-year storage in liquid nitrogen, embryos were thawed and transplanted into two oestrus-synchronised recipient hinds. For the purpose of synchronisation the animals were treated with CIDR type $\mathrm{G}$ implantation for 8 days and on the withdrawal day with 300 IU PMSG (Folligon inj.). Removal of the cryoprotective agent was performed in three steps using sucrose (Curtis, 1991). Embryos were surgically transferred into the ipsilateral uterine horn 7 days after heat.

Each hind was immobilised by the application of a combination of xylazine and ketamine (Rometar 2\% inj., Spofa, Prague; Calypsovet inj., PhylaxiaSanofi, Budapest) prior to insemination, embryo collection and embryo transfer.

\section{Results}

Sperm was collected from the epididymides of 11 stags. The quality of the spermatozoa of 6 stags met the requirements for final dilution. The stags used in the study weighed $162-200 \mathrm{~kg}$ after field dressing (i.e., with skin, but without the head, feet and viscera) and had trophy weights of $6.9-14.7 \mathrm{~kg}$ including the skull. After deep-freezing, the extended sperm provided 8.6-25.7 $\times 10^{6}$ viable spermatozoa per straw. After thawing, $40-50 \%$ of the spermatozoa exhibited vigorous progressive motility. Between 3 and $8 \%$ of mature spermatozoa were detected as having primary morphological defects, and between 1 and $5 \%$ of the spermatozoa were found to be immature, while none showed acrosomal damage (Table 1). Bacteriological examinations revealed that the viable aerobic bacterial count was consistently below $10^{4} / \mathrm{ml}$ sperm. Sperm samples diluted 1:100 were negative for Escherichia coli and all samples were negative for moulds and pathogens. 
Table 1

Characteristics of frozen-thawed sperm from shot red deer stags

\begin{tabular}{|c|c|c|c|c|c|c|c|c|}
\hline \multirow[t]{2}{*}{$\begin{array}{l}\text { No. } \\
\text { of } \\
\text { stags }\end{array}$} & \multirow{2}{*}{$\begin{array}{l}\text { Time of } \\
\text { sperm } \\
\text { dilution } \\
\text { h }\end{array}$} & \multirow{2}{*}{$\begin{array}{c}\text { Hours } \\
\text { of } \\
\text { freezing } \\
\mathrm{h}\end{array}$} & \multirow{2}{*}{$\begin{array}{c}\text { Pre- } \\
\text { freezing } \\
\text { motility } \\
\%\end{array}$} & \multicolumn{2}{|c|}{$\begin{array}{l}\text { Post-thaw motility } \\
\text { Progressively motile } \\
\text { spermatozoa }\end{array}$} & \multirow{2}{*}{$\begin{array}{l}\text { Primary } \\
\text { mor- } \\
\text { phological } \\
\text { disorders } \\
(\%)\end{array}$} & \multirow{2}{*}{$\begin{array}{c}\text { Acrosomal } \\
\text { disorders } \\
(\%)\end{array}$} & \multirow{2}{*}{$\begin{array}{c}\text { Imma- } \\
\text { turity } \\
(\%)\end{array}$} \\
\hline & & & & $\%$ & $\begin{array}{c}\times 10^{6} / \\
0.25 \mathrm{ml}\end{array}$ & & & \\
\hline 1 & 3 & 14 & $>90$ & 45 & 25.7 & 7 & 0 & 3 \\
\hline $2^{\mathrm{a}}$ & 17 & 37 & $\sim 80$ & 50 & 23.5 & 3 & 0 & 1 \\
\hline $2^{b}$ & 17 & 37 & $\sim 80$ & 40 & 12.5 & 3 & 0 & 3 \\
\hline 3 & 17 & 37 & $>80$ & 40 & 24.8 & 8 & 0 & 2 \\
\hline 4 & 2 & 36 & $>90$ & 45 & 8.6 & 5 & 0 & 2 \\
\hline 5 & 4 & 9 & $\sim 80$ & 50 & 17.0 & 4 & 0 & 1 \\
\hline 6 & 4 & 40 & $\sim 80$ & 40 & 11.8 & 3 & 0 & 5 \\
\hline
\end{tabular}

${ }^{a}$ sampled from right epididymis; ${ }^{b}$ sampled from left epididymis

During an in vivo capacitation experiment performed in 1993 with red deer sperm stored frozen for two years, on Day 7 after a single intrauterine insemination through the cervix, 12 ova and 7 first-class embryos suitable for deep-freezing were recovered from the three hinds involved (Table 2).

Embryo transfer was successful in one of these hinds, which gave birth to a normal stag fawn in June 1996.

Table 2

Results of embryo collection from superovulated farmed hinds

\begin{tabular}{|c|c|c|c|}
\hline Serial number & $\begin{array}{c}\text { Time of artificial } \\
\text { insemination after removal } \\
\text { of CIDR-G (h) }\end{array}$ & $\begin{array}{l}\text { No. of ovulations } \\
\text { (corpora lutea) }\end{array}$ & $\begin{array}{l}\text { Embryos or } \\
\text { ova recovered }\end{array}$ \\
\hline 1 & 60 & 4 & $\begin{array}{l}3 \text { blastocysts } \\
1 \text { ovum }\end{array}$ \\
\hline 2 & 60 & 18 & $\begin{array}{l}1 \text { morula } \\
7 \text { ova }\end{array}$ \\
\hline 3 & 60 & 7 & $\begin{array}{l}3 \text { morulae } \\
4 \text { ova }\end{array}$ \\
\hline
\end{tabular}




\section{Discussion}

The influence exerted by seasonality on the quality of red deer semen was investigated by Krzywinski and Jaczewski (1978) and Haigh et al. (1985). These authors found that sperm morphology varied with season, and that good-quality semen could be obtained during the breeding season, up to March. The sperm used in this study was collected from stags shot during the roaring season.

In ejaculates from 13 red deer stags collected into an artificial vagina, Krzywinski (1976) found that the volume of semen was between 1.5 and $3.5 \mathrm{ml}$ and its spermatozoon concentration ranged between $0.1 \times 10^{9}$ and $3.8 \times 10^{9}$ per ml. Jaczewski et al. (1976) electroejaculated three stags in the rutting period; the average volume of that semen was found to be $2.0 \mathrm{ml}$, while its spermatozoon concentration ranged between $460 \times 10^{3}$ and $1.285 \times 10^{3}$ per $\mathrm{ml}$. The proportion of viable spermatozoa was $80 \%, 40-80 \%$ of which showed progressive motility. Frozen-thawed red deer semen diluted with goat semen extender was found to contain $35-40 \%$ spermatozoa showing progressive motility. In this study, the concentration of sperm obtained directly from the epididymides and free from secretions of the accessory sex glands - according to the calculations of the authors, before dilution (between $1.5 \times 10^{9}$ and $4.5 \times 10^{9} \mathrm{ml}$ ) - was higher than that of the semen of red deer. The ratio of viable spermatozoa was consistently above than $80 \%$, a fact which may account for the relatively high post-freezing survival rate (40-50\%). A particularly important observation is that when testing the sperm collected from two stags killed in the evening hours the next morning, i.e. 17 hours after the stags' death, the sperm was found to be suitable for freezing. The maximum survival time of spermatozoa in yolk diluent at $5{ }^{\circ} \mathrm{C}$ has been reported to be 18 days (Krzywinski, 1976). The studies performed by the authors demonstrate that sperm samples diluted and stored at $4{ }^{\circ} \mathrm{C}$ could possibly be appropriate for freezing within 40 hours.

Asher et al. (1992) obtained an almost identical fertilisation rate after intravaginal insemination of fallow deer hinds with fresh and frozen-thawed semen containing $85 \times 10^{6}$ motile spermatozoa per dose.

In sperm collected post mortem from two white-tailed deer the ratio of spermatozoa demonstrating progressive motility was $5 \%$ and $35 \%$, respectively; that is, much lower than in electroejaculated semen, in which the same ratio has been found to be between 60 and 70\% (Jacobson et al., 1989). Despite this, the above authors achieved a conception rate of $67 \%$ after intravaginal insemination of tris-yolk extended sperm from the two killed deer.

In accordance with the semen evaluation method described by Haigh et al. (1985), the frozen semen of wapiti should contain $20-30 \times 10^{6}$ spermatozoa per $\mathrm{ml}$ in straws containing ejaculates prepared for freezing, in order that the postthaw semen should meet the minimum quality requirements. Semen is suitable 
for deep-freezing if it conforms to the following parameters: $>80 \%$ spermatozoa with normal morphology; $<10 \%$ spermatozoa with head or middle part defects; and $>80 \%$ spermatozoa showing progressive motility.

In these studies all three superovulated hinds conceived after a single intrauterine insemination with semen containing $23.5 \times 10^{6}$ spermatozoa per $0.25 \mathrm{ml}$, and the subsequently yielded embryos were suitable for deep-freezing. According to preliminary results, the tris-yolk dilution of sperm obtained from the epididymis and free from the secretions of accessory sex glands did not affect sperm capacitation.

The findings obtained by the authors indicate that the genetic material of the most valuable hunted red deer stags can be saved post mortem by means of the method outlined here. The establishment of a red deer gene bank would thus remedy the deficiency caused in game husbandry and animal breeding, for the purpose of ensuring genetic preservation and/or genetic progress. The specific utilisation of deep-frozen sperm may improve the genetic work and efficiency of red deer farms. Coupled with embryo transfer, the use of sperm of high genetic value may create a feasible means of ensuring rapid genetic progress.

\section{Acknowledgements}

The authors thank Dr. G. Galamb, I. Böhm and T. Hefter for the sperm collection possibility, the late Dr. P. Sutka for evaluation of the quantitative and qualitative parameters of sperm samples, Dr. F. Jakab for laboratory works related to sperm freezing, and I. Nagy and T. Dani for technical help in embryo transfer.

\section{References}

Asher, G. W., Adam, J. L., Otway, W., Bowmar, P., Van Reenen, G., Mackintosh, C. G. and Dratch, P. (1988a): Hybridization of Père David's deer (Elaphurus davidianus) and red deer (Cervus elaphus) by artificial insemination. J. Zool. 215, 197-203.

Asher, G. W., Adam, J. L., James, R. W. and Barnes, D. (1988b): Artificial insemination of farmed fallow deer (Dama dama): fixed-time insemination at a synchronized oestrus. Anim. Prod. 47, 487-492.

Asher, G. W., Morrow, C. J., Jabbour, H. N., Mulley, R. C., Veldhuizen, F. A. and Langride, M. (1992): Laparoscopic intra-uterine insemination of fallow deer with frozen-thawed or fresh semen after synchronisation with CIDR devices. N. Z. Vet. J. 40, 8-14.

Curtis, J. L. (1991): Embryo freezing. In: Curtis, J. L. (ed.) Cattle Embryo Transfer Procedure. Academic Press, Inc., San Diego, USA. pp. 67-89.

Fennessy, P. F., Mackintosh, C. G. and Shackell, G. H. (1990): Artificial insemination of farmed red deer (Cervus elaphus). Anim. Prod. 51, 613-621.

Haigh, J. C. (1984): Artificial insemination of two white-tailed deer. J. Am. Vet. Med. Assoc. 18, $146-147$. 
Haigh, J. C., Barth, A. D., Cates, W. F. and Glover, G. J. (1985): Electroejaculation and semen evaluation of wapiti. Biol. Deer Prod. 22, 197-203.

Haigh, J. C. and Bowen, G. (1991): Artificial insemination of red deer (Cervus elaphus) with frozen-thawed wapiti semen. J. Reprod. Fert. 93, 119-123.

Hungarian Standard MSZ 7061 (1987): Deep-frozen bull semen. No. 40. (in Hungarian).

Jacobson, H. A., Bearden, H. J. and Whitehouse, D. B. (1989): Artificial insemination trials with white-tailed deer. J. Wildl. Manage. 53, 224-227.

Jaczewski, Z., Morstin, J., Kossakowski, J. and Krzywinski, A. (1976): Freezing the semen of red deer stags. VIIIth Intern. Congress on Animal Reprod. and Artificial Insemination, Kraków, 12-16 July, Proceedings Vol. 1. Comm. Abstr. 116.

Krzywinski, A. (1976): Collection of red deer semen with the artificial vagina. VIII Intern. Congress on Animal Reprod. and Artificial Insemination, Kraków, 12-16 July, Proceedings Vol. 1. Comm. Abstr. 114.

Krzywinski, A. and Jaczewski, Z. (1978): Observations on the artificial breeding of red deer. Symp. Zool. Soc. Lond. No. 43, 271-287.

Mulley, R. C., Moore, N. W. and English, A. W. (1988): Successful uterine insemination of fallow deer with fresh and frozen semen. Theriogenology 29, 1149-1153. 